\title{
Bacillus spores: a review of their properties and inactivation processing technologies
}

\author{
Won-Il Cho ${ }^{1} \cdot$ Myong-Soo Chung ${ }^{1}$
}

Received: 12 May 2019/Revised: 2 August 2020/Accepted: 7 August 2020/Published online: 6 October 2020

(C) The Author(s) 2020

\begin{abstract}
Many factors determine the resistance properties of a Bacillus spore to heat, chemical and physical processing, including thick proteinaceous coats, peptidoglycan cortex and low water content, high levels of dipicolinic acid (DPA), and divalent cations in the spore core. Recently, attention has been focused on non-thermal inactivation methods based on high pressure, ultrasonic, high voltage electric fields and cold plasmas for inactivating Bacillus spores associated with deterioration in quality and safety. The important chemical sporicides are glutaraldehyde, chorine-releasing agents, peroxygens, and ethylene oxide. Some food-grade antimicrobial agents exhibit sporostatic and sporicidal activities, such as protamine, polylysine, sodium lactate, essential oils. Surfactants with hydrophilic and hydrophobic properties have been reported to have inactivation activity against spores. The combined treatment of physical and chemical treatment such as heating, UHP (ultra high pressure), PEF (pulsed electric field), UV (ultraviolet), IPL (intense pulsed light) and natural antimicrobial agents can act synergistically and effectively to kill Bacillus spores in the food industry.
\end{abstract}

Keywords Spore formation - Germination - Resistance properties - Sporicidal agents - Non-thermal inactivation processing

Myong-Soo Chung

mschung@ewha.ac.kr

1 Department of Food Science and Engineering, Ewha Womans University, Seoul, Republic of Korea

\section{Introduction}

Many species of spore-forming bacteria are associated with food spoilage (Gould, 2006; Stragier and Losick, 1996). Bacterial endospores, especially Bacillus species, are the inactivation target in various forms of food processing. One of the most important microorganisms as significant pathogens in humans or involved in quality damage, Bacillus genus such as B. subtilis, B. amyloliquefaciens, $B$. cereus, B. licheniformis, B. pumilus, and B.thuringiensis, etc. are a rod-shaped, gram-positive bacterium that are naturally found in soil and vegetation. Specifically, $B$. cereus and $B$. anthrax are representative pathogenic spore forming bacteria, and B. subtilis, B. stearothermophilus and $B$. amyloliquefaciens are the main bacteria that cause degradation of processed foods. Therefore, killing Bacillus spores associated with pathogenicity and deterioration is important for sterilization of processed foods (Higgins and Dworkin, 2012; Leuschner and Lillford, 2003). The representative Bacillus spores associated with pathogenicity are $B$. cereus. The pathogenicity of $B$. cereus contamination, whether intestinal or nonintestinal, is intimately associated with the production of tissue-destructive exoenzymes. Among these secreted toxins are four hemolysins, three distinct phospholipases, an emesis-inducing toxin, and proteases (Higgins and Dworkin, 2012; Soni et al. 2016).

Bacillus endospores are difficult to control in the food industry because their spores have relatively high resistances to physical and chemical treatments (Ablett et al., 1999; Higgins and Dworkin, 2012; Leuschner and Lillford, 2003; Russell, 1990; Setlow and Setlow, 1995). Dormant bacterial endospores are much more resistant than vegetative cells to common inactivation and disinfection treatments, including heat, radiation, and various chemicals 
(Amador-Espejo et al., 2014; Anderson et al., 2000; Banksm et al., 1988; Gould, 2006; Peleg and Cole, 2000; Russell, 1990; Setlow and Setlow, 1995).

Processes designed to inactivate Bacillus spores in foods need to take this high level of resistance into account. Special attention must also be given to the processing and preserving of foods so that the spores are either inactivated or prevented from undergoing germination and outgrowth. Focusing on the research results of the last 5 years, this review article summarizes related studies on their biochemical and growth properties and the novel inactivation technologies of Bacillus spores.

\section{History of the discovery of spore}

\section{Sporulation}

Bacterial endospores were first studied 130 years ago by Cohn and Koch in 1876, independently. Cohn conducted experiments to understand about the new science of bacteriology, and Koch first described the complete sporulation-germination-multiplication-resporulation life cycle of sporeformers in 1888 (Ablett et al., 1999; Atrih and Foster, 2002; Gould, 2006; Leuschner and Lillford, 2003; Stragier and Losick, 1996). Following Koch's primary observation, detailed description of spore formation using an optical microscope was made by Knaysi (1938) (Ablett et al., 1999; Gould, 2006; Stragier and Losick, 1996). FitzJames (1960) studied to describe asymmetric septation, engulfment and the sequential formation of the spore with the electron microscopy (Ablett et al., 1999; Leuschner and Lillford, 2003; Setlow and Setlow, 1995). These studies lead to the subdivision of the sporulation sequence into seven distinct stages by Ryter et al. (1966), which became the key basis for sporulation studies and remains so today (Ablett et al., 1999; Gould, 2006). And genetic studies were carried out to investigate for developmental sequence of transformation with numerous sporulation-defective mutants of B. subtilis by Errington (1993) and to uncover the controlling sigma cascade by Stragier and Losick (1996) and Sonnenshein (2000) (Ablett et al., 1999; Atrih and Foster, 2002; Gould, 2006; Leuschner and Lillford, 2003; Stragier and Losick, 1996).

\section{Germination}

Powell and Strange (1953) conducted the discovery of high levels of calcium, and determination of the structure of dipicolinic acid (DPA) and the identification of muramic acid in the peptidoglycan fragments that leaked from germinating spores (Ablett et al., 1999; Gould, 2006; Stragier and Losick, 1996). The first genetic studies on germination were initiated by Smith, Moir and their colleagues in the $1980 \mathrm{~s}$, which led to the identification of germination receptors (Ablett et al., 1999; Gould, 2006; Stragier and Losick, 1996). And the trigger' reactions on spore germination were identified action of germination enzymes, first by Foster and Johnstone (1990) (Gould, 2006; Stragier and Losick, 1996).

Cohn observed that new media supported germination, and Hills (1949) identified L-alanine and some other amino acids (including l-aminobutyric acid, L-cysteine, L-valine and L-leucine) as the specific chemicals that caused germination of the spores of various Bacillus species (Ablett et al., 1999; Gould, 2006; Russell, 1990; Stragier and Losick, 1996).

Ribosides (adenosine, inosine, guanosine and xanthosine) were shown to be effective germinants for some types of Bacillus spores and to be synergistic with the specific amino acid germinants. Levinson and Hyatt (1966) first discovered the effectiveness of certain sugars and amino sugars (glucose, fructose, 2-deoxyglucose, glucosamine and $\mathrm{N}$-acetylglucosamine) as germinants for Bacillus spores, and their synergy with amino acids and cations $\left(\mathrm{K}^{+}\right)$(Atrih and Foster, 2002; Gould, 2006; Russell, 1990).

Mild preheating induced rapid subsequent germination of spores in the presence of specific germinants. Ablett et al. (1999) suggested that the germination mechanism of spore protoplasts by heat activation may be in a glassy state from temperature-induced glass transition (Gould, 2006; Stragier and Losick, 1996).

\section{Biochemical and growth properties of Bacillus spores}

\section{Sporogenesis and germination}

Spores are generally formed when the vegetative organism is stressed by limiting the availability of nutrients, and pathogens allow it to survive in a dormant state outside the aerobic or anaerobic environment of the intestine until a new host is colonized (Atrih and Foster, 2002; Higgins and Dworkin, 2012; Russell, 1990).

The Gram-positive bacteria $B$. subtilis can initiate the sporulation process under nutrient restriction conditions. The morphological mechanism of the sporulation process (Fig. 1) generally consists of seven stages as follows: cell division is stopped by a spore-formation signal, and the nuclear material is disposed axially into filaments the nuclear material becomes denser in stage I. The plasma membrane then invaginates to form a spore septum in stage II, and completion of DNA segregation occurs concurrently with the invagination of the plasmatic membrane in an 

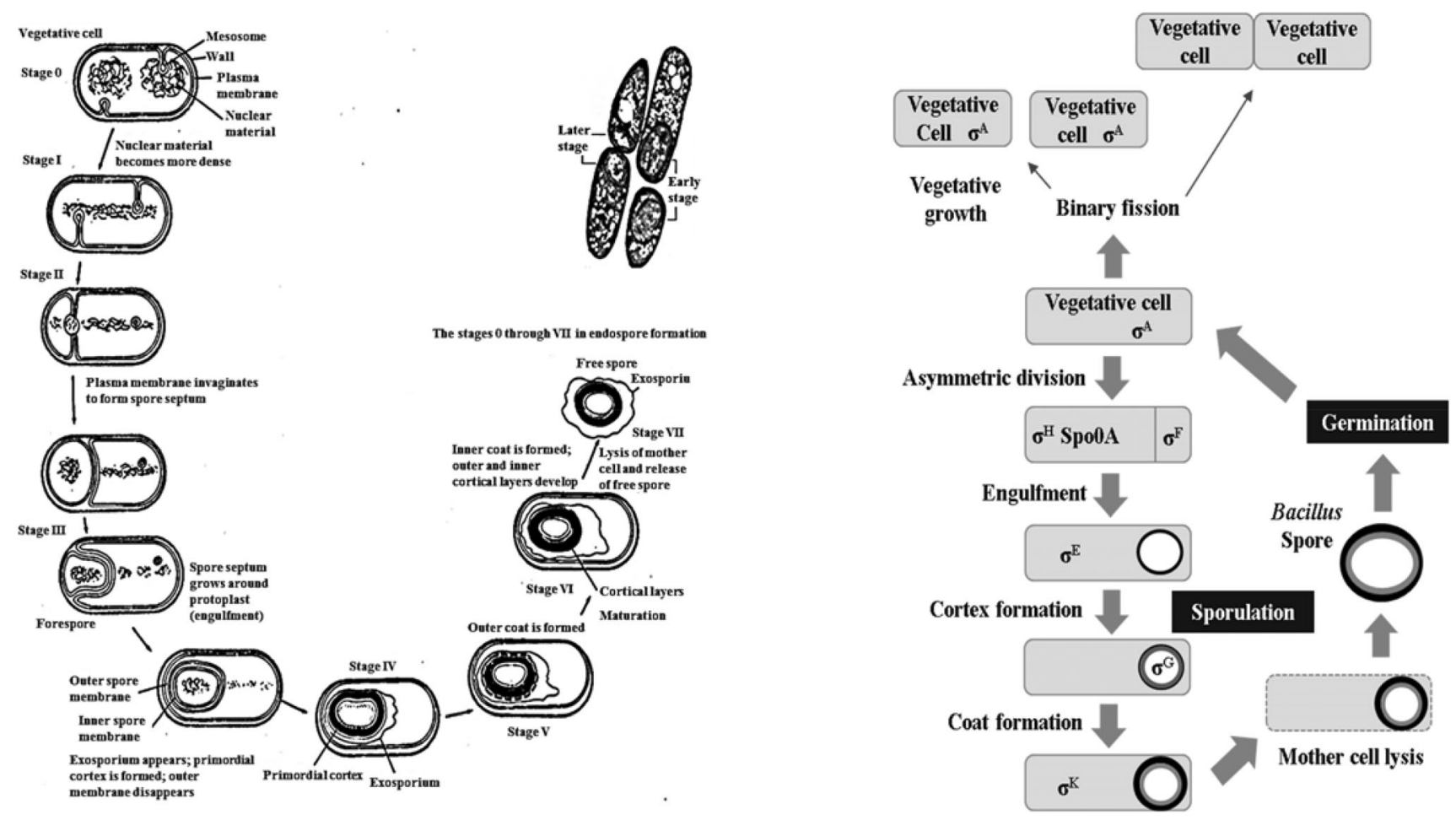

Fig. 1 Schematic representation of B. subtilis spore formation based on morphological mechanism (Atrih and Foster, 2002; de Hoon et al., 2010; Driks, 1999; Higgins and Dworkin, 2012; Gould, 2006; Russell, 1990; Sandra et al., 2014; Sekiguchi et al., 1999; Setlow et al., 2000)

asymmetric position, near one pole of the cell, forming a septum. The exosporium appears, the primordial cortex is formed, and the outer membrane disappears sequentially in stages III and IV. Specifically, spores, the septum begins to curve, and the immature spore is surrounded by a double membrane of the mother cell in an engulfment process, similar to phagocytosis, and the smaller fore-spore becomes entirely contained within the mother cell in stages III. The mother cell mediates the development of the forespore into the spore in stage IV. Then, the inner and outer proteinaceous layers of the spores are assembled, and the spore cortex composed of a thick layer of peptidoglycan contained between the inner and outer spore membranes is synthesized. Moreover, calcium dipicolinate accumulates in the nucleus in stage IV (Atrih and Foster, 2002; de Hoon et al., 2010; Higgins and Dworkin, 2012; Gould, 2006; Sandra et al., 2014; Sekiguchi et al., 1999; Setlow et al., 2000).

The formation of the outer and inner coats continues with the development of outer and inner cortical layers in stages V and VI. The spore coat is synthesized, consisting of proteins deposited by the mother cell, and is arranged in inner and outer layers in stage $\mathrm{V}$. The formation of the coat begins just after the formation of the sporulation septum. At that time the protein called SpoIVA binds at or very close to the adjacent mother cell (Meador-Parton and Popham, 2000). In the second stage, SpoIVA connects the preliminary coat structure, called the precoat, to the mother-cell side of the forespore (Riesenman and Nicholson, 2000). In the last stage, the precoat is a 181-aminoacid protein called CotE with a stretch of acidic residues between amino acids 150 and 169 (Heo and Cho, 2002). After the precoat is assembled, the inner coat protein penetrates into the backbone formed by the precoat and the outer-coat protein is assembled around the shell of the CotE protein (Fig. 2) (Meador-Parton and Popham, 2000; Sekiguchi et al., 1999). Spore maturation occurs during this stage, and the spores become resistant to heat and organic solvents in Stage V. Finally, lysis of the mother cell and release of a free mature spore occurs in stage VII (Fig. 1) (Atrih and Foster, 2002; de Hoon et al., 2010; Higgins and Dworkin, 2012; Gould, 2006; Russell, 1990; Sandra et al., 2014).

Comparative studies have described the biochemical mechanisms of spore formation based on cascade theory (Driks, 1999; Setlow et al., 2000). In this mechanism, the signal for spore formation is first transferred by the phosphoryl system with a multicomponent regression function. The continuous expression of a spore-forming gene called a sigma $(\sigma)$ cascade controls the mechanism of spore formation. The expression of the gene related the spore formation is controlled by six kinds of $\sigma$ factor (designated as $\mathrm{A}, \mathrm{H}, \mathrm{F}, \mathrm{E}, \mathrm{G}$, and $\mathrm{K}$ ): the A factor is related to housekeeping and early sporulation on vegetative-cell, the $\mathrm{H}$ 


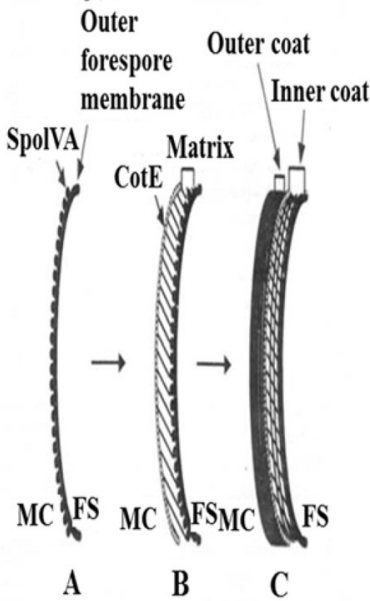

(A)

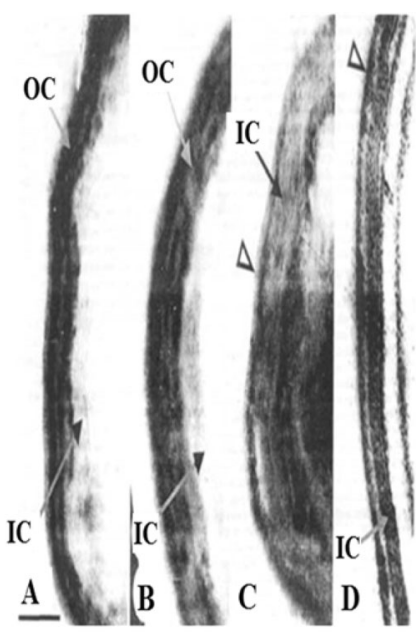

(B)
Fig. 2 (A-I) Model of the stages of coat formation: [A] SpoIVA localizes to the mother-cell (MC) side of the sporulation septum, of which only an arc is shown; [B] the precoat, consisting of the matrix and the layer of CotE protein, assembles at the forespore (FS) surface, under the direction of SpoIVA; and [C] the inner-coat (IC) proteins assemble into the matrix and the outer-coat (OC) proteins bind the shell of CotE. (A-II) Electron microscopy images of wild-type and mutant spore coats, showing arcs of wild-type [A], AD408 [B], TB50 $[C]$, and TB70 [D] spore coats. The open arrowheads indicate thin remnants of the outer coat. Bar, $100 \mathrm{~nm}$ (Meador-Parton and Popham, 2000; Sekiguchi et al., 1999)

factor induces the expression of gene-related spore formation by sporulation regulatory genes (Spo0A-P), which is the beginning stage. And the $\mathrm{E}$ factor is involved in the early mother cell gene expression, the $\mathrm{F}$ factor is concerned with early forespore gene expression, the $\mathrm{K}$ factor is related to the formation of the spore-coat proteins, and the $\mathrm{G}$ factor induces the gene with UV-radiation resistance (Fig. 3) (Driks, 1999; Irene and Kumaran, 2014; Sekiguchi et al., 1999; Setlow et al., 2000).

Recently, Higgins and Dworkin (2012) reported in detail the morphological changes during the sporulation process

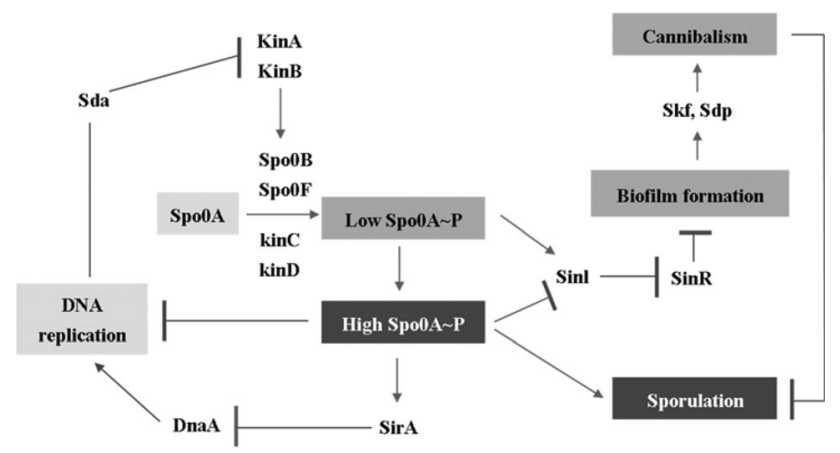

Fig. 3 Schematic representation of $B$. subtilis spore formation based on biochemical mechanism (Atrih and Foster, 2002; Driks, 1999; Higgins and Dworkin, 2012; Irene and Kumaran, 2014; Gould, 2006; Russell, 1990; Sekiguchi et al., 1999; Setlow et al., 2000) based on the activation of different sigma specific transcription factors (H, F, E, G and _K) in each spore compartment. First, high levels of $\mathrm{H}$ and Spo0A trigger sporulation and lead to the expression of pro-F, and then $\mathrm{F}$ is activated only in the forespore by asymmetric division. The SpoIIR protein is produced under the control of $\mathrm{F}$ and secreted by the forespore, and activates the proteolytic processing of pro-E $\rightarrow \mathrm{E}$ in the mother cell. After engulfment is complete, a signal produced in the mother cell under the control of $\mathrm{E}$ enters the forespore via the SpoIIIAH/SpoIIQ pore and activates G. Finally, the SpoIVB protein produced under the control of $G$ in the forespore activates pro- $\mathrm{K} \rightarrow \mathrm{K}$ proteolytic processing in the mother cell via an interaction with the SpoIVFA/ SpoIVFB/BofA complex (Fig. 3). (Atrih and Foster, 2002; Higgins and Dworkin, 2012; Irene and Kumaran, 2014; Gould, 2006; Russell, 1990).

A summary of the core mechanisms of spore formation is as follows. The biochemical mechanism underlying the formation of Bacillus spores has been explained using sigma $(\sigma)$ cascade theory. The continuous expression of spore-forming gene is controlled by six kinds of $\sigma$ factor (designated as A, H, F, E, G, and K).

Spores can remain dormant for long periods of time and retain significant resistance to environmental damage such as heat, radiation, toxic chemicals, and extreme $\mathrm{pH}$. Spores of Bacillus species can remain in their dormant and resistant states for years, but when exposed to specific nutrients, spores can return to life within minutes of germination and out-growth. Germination is generally triggered by the presence of nutrients, including amino acids, sugar, and nucleosides (Paidhungat et al., 2001). The process consists of several events in which the exact temporal order has not been clearly determined.

Spore germination induced by nutrients has been divided into stage I, which consists of events that occur in the absence of cortex hydrolysis, and stage II, which consists of all subsequent events, including cortex hydrolysis (Fig. 4) (Gould, 2006; Moriyama, 1998; Paidhungat et al., 2001; Paredes-Sabja et al., 2011; Russell, 1990; Sandra et al., 2014; Setlow, 2014). Some events related to germination at stage I, called activation, occur in the spore core and rehydrate the dehydrated cytoplasm of the spores and excrete large amounts of stored DPA (pyridine-2,6dicarboxylic acid or dipicolinic acid) and contains divalent cations, $\mathrm{Ca}^{2}{ }^{+}$is dominant. It is currently thought that the interaction of nutrients and their receptors in the inner membrane of a spore changes the permeability of that membrane. The most common, initial step in the germination process is the recognition of small molecule germinants by germination (Ger) receptors. Ger receptors are inner-membrane heterogeneous complexes formed by three distinct protein products such as the A-, B-, and C-subunits 


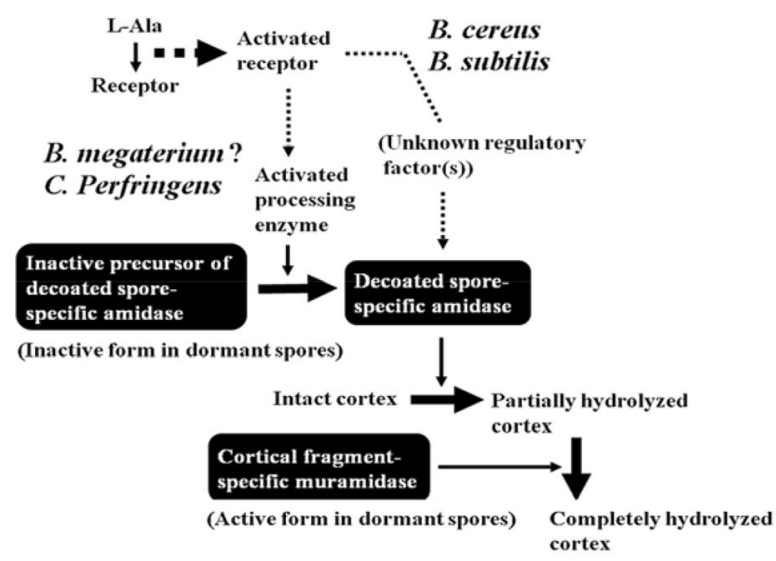

Fig. 4 Model of Bacillus spore germination. Nutrient-induced spore germination has been divided into stage I, which consists of events that occur in the absence of cortex hydrolysis, and stage II, which consists of all subsequent events, including cortex hydrolysis (Gould,

(Ross and Abel-Santos, 2010). Specifically, the initiation or triggering process in response to nutritional replenishment that occurs when the germinating molecules such as lowmolecular-weight amino acids, sugars, and purine nucleosides, are sensed by germination receptors (GRs) located in the inner membrane of the Bacillus spore. These receptors include, gerA, gerB, or gerK, and the germinating molecules bind these receptors. L-alanine acts through the gerA receptor, and a mixture of L-asparagine, fructose, glucose and $\mathrm{KCl}$ (AGFK) bind the gerB and gerK receptors (Fig. 4). (Gould, 2006; Paredes-Sabja et al., 2011; Sandra et al., 2014; Setlow, 2014; Zhang et al., 2013; Zhang et al., 2012). And this phenomenon leads to the release of DPA and cations from the spore core with water absorption, and then leads to spore germination in the stage II (Fig. 4) (Gould, 2006; Moriyama, 1998; Paidhungat et al., 2001; Paredes-Sabja et al., 2011; Sandra et al., 2014; Sekiguchi et al., 1999; Setlow, 2014). Specifically, DPA (pyridine2,6-dicarboxylic acid) is degraded and released, the rehydration of the spore core in the stage II is followed. Rehydration allows the initiation of protein mobility and reactivation of bio-chemical processes during outgrowth (Zhang et al. 2010).

The hydrolysis reaction in the spore cortex associated with stage II is not necessary for germination events in the spore core. The cortex hydrolysis is absolutely necessary for the subsequent steps in germination that, including the initiation of spore metabolism and the growth of the germinated spore. The energy needs in the early stage of growth are met by the catabolism of compounds such as 3-PGA (3-phosphoglycolic acid) stored in the core, and all events that make up the germination process occur without energy metabolism PGM. Cortex hydrolysis is another stage of germination that has been studied in some detail. Hydrolysis of the cortex during spore germination involves

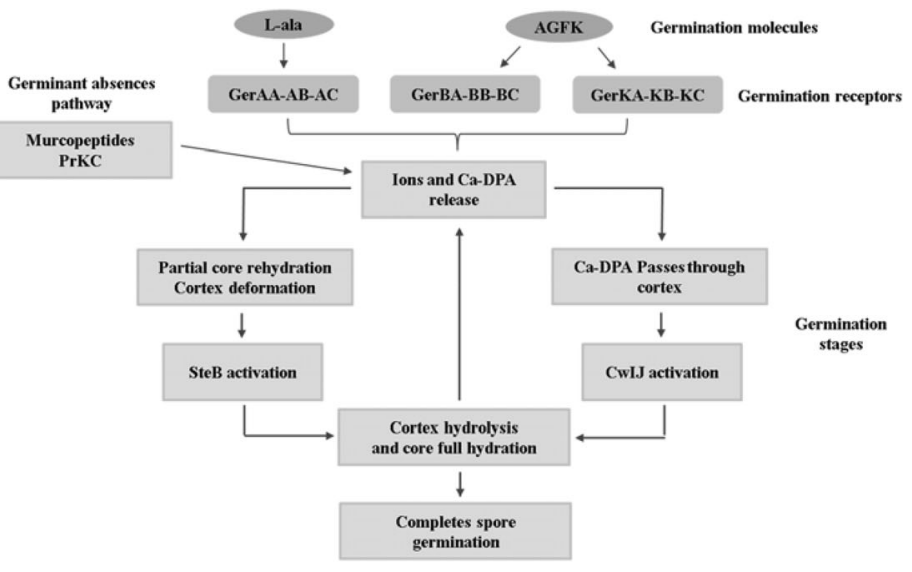

2006; Moriyama, 1998; Paidhungat et al., 2001; Paredes-Sabja et al., 2011; Sandra et al., 2014; Sekiguchi et al., 1999; Setlow, 2014; Zhang et al., 2012; 2013)

several spore enzymes called cortex-lytic enzymes (CLE). Two CLEs, named SleB and CwlJ, have been implicated in cortex hydrolysis in $B$. subtilis during nutrient-induced spore germination (Paidhungat et al., 2001).

Spore germination is most commonly triggered by specific nutrients, but it can also be induced by certain chemicals that are not nutrients and by physical treatment such as ultra-high pressure, ultrasound, and electric fields (Moriyama, 1998; Paidhungat et al., 2001; Russell, 1990; Sekiguchi et al., 1999; Setlow, 2014). The best-known example of a nonnutrient chemical germinant is a $1: 1$ chelate of $\mathrm{Ca}^{2+}$ and DPA, which triggers the germination of spores in many species of endospore-forming bacteria. The nutrient germinants bind to specific spore receptors that are encoded by the three expressed members of the gerAfamily of operons. As a result, $\mathrm{Ca}^{2+}$ and DPA are expected to trigger cortex hydrolysis, but it is not known whether the same two CLEs are used in the process (Driks, 2002; Moriyama, 1998; Paidhungat et al., 2001; Russell, 1990; Setlow, 2014). It is very interesting that the mechanisms of nutrients and $\mathrm{Ca}^{2+}$ are different and that DPA causes spore germination at least at the receptor-mediated stage (Gould, 2006; Moriyama, 1998; Paidhungat et al., 2001; Russell, 1990; Setlow, 2014).

Spore coat hydrolysis allows the emergence of the incipient vegetative cell. Outgrowth is the transition of the germinated spore to a growing cell, during which time cell division occurs. During the first stage of outgrowth, ATP is generated through the conversion of 3-phosphoglycerate stored in the spore core. At a later stage, the outgrowing spores are converted to the use of extracellular nutrients (Zhang et al., 2010). Initiation of etching and outgrowth of the coat layer typically occurred within $1-2 \mathrm{~h}$ and 3-7 h, respectively. During germinant absences, the germination of Bacillus spores may also be triggered by extremely low 
concentrations of muropeptides. Muropeptides are produced by the degradation of peptidoglycans that comprise the cell wall of the majority of bacteria and spore coats (Zhang et al., 2013; 2012).

A summary of the core mechanisms of germination is as follows. Germination occurs in the spore core and includes rehydration of the spore's somewhat dehydrated cytoplasm and excretion of a large amount of stored DPA (pyridine2,6-dicarboxylic acid) and divalent cations, predominantly $\mathrm{Ca}^{2+}$. Cortex-lytic enzymes have been implicated in hydrolysis of the cortex during spore germination.

\section{Susceptibility and resistance}

There are many factors that determine the resistance properties of spores, including the thick proteinaceous coat, low water content and high levels of DPA and divalent cations in the spore core (Table 1) (Atrih and Foster, 2002; Driks, 2002; Riesenman and Nicholson, 2000).

The extreme outer layer of Bacillus spores, exosporium, consists of glucose, lipids and proteins (Atrih and Foster, 2002; Driks, 2002; Russell, 1990). The exosporium constitutes the first barrier between the spore and the environment. It may contribute to protection against damaging macromolecules such as hydrolytic enzymes and antibodies. And also, the exosporium provides resistance to oxidative stress generated by macrophages (Atrih and Foster, 2002; Driks, 2002; Riesenman and Nicholson, 2000).

The double membrane of Bacillus spores surrounding the spore cytoplasm contains proteins and lipids essential for membrane structure. Unlike the outer membrane, the spore's inner membrane is a strong permeable barrier to many chemicals that damage DNA (Atrih and Foster, 2002; Driks, 2002; Russell, 1990).

The spore coating provides the first line of defense against chemical treatment and consists of two layers of proteins that are resistant to mechanical shocks such as high pressure and electrical energy (Amador-Espejo et al., 2014; Cho et al., 1999; Hayakawa et al., 1998; Marquez et al., 1997; Oh and Moon, 2003). The spore coat of $B$. subtilis is a triple-layered structure consisting of an outer coat, an inner coat (crust), and an electron-diffuse undercoat as revealed by electron microscopy (Soni et al., 2016). The spore coat is composed of proteins and glycoproteins and acts as a filter for many molecules such as enzymes, nutrients, and it detoxifies chemicals related to cause damage for spore (Driks, 2002; Setlow, 2006).

The layer under the spore coat consists of a thick layer of peptidoglycan, called the cortex, which covers the core and protects it from chemical damage by organic solvents (Riesenman and Nicholson, 2000). The structure of the Bacillus spore contains the peptidoglycan cortex that protects the spore's inner membrane, which is an important barrier stopping the entry of small hydrophilic molecules into the central spore core (Atrih and Foster, 2002; Jeffrey et al., 2003). The cortex is composed of a matrix structure constructed from peptidoglycan, glycopeptide (spore mucopeptide), and $\mathrm{Ca}^{2+}$, and it is resistant to heat and $\mathrm{UV}$ radiation (Sun et al., 2016). The cortex functions to accept the germinant and induce the disassembly of the cortex by a hydrolysis enzyme in the middle of spore cores and coats (Moriyama, 1998).

The layer beneath the germ cell wall is an inner membrane that acts as a barrier to chemicals, protecting the central core (Setlow, 2006). Strong resistance to heat and chemical treatment of Bacillus spores is due to the unique structure and properties of the core (Atrih and Foster, 2002; Driks, 2002). The central core consists of ribosomes, inert enzymes, and small acid-soluble binding proteins (SASP) that protect the DNA, which is present in the form of a chromatin network (Setlow, 2014). And also, this core is similar to the nucleus of vegetable cells from the functional aspect, but the DNA of core contains SASP, DPA, Ca, Mg, and $\mathrm{Mn}$ at high concentrations to produce a high resistance to heat denaturation and radiation. The dry state of the core caused by the contractile cortex mechanism is another important factor in increasing the heat resistance of Bacillus spores (Riesenman and Nicholson, 2000; Russell, 1990).

As a recent related study, the heat resistance of $B$. subtilis spores was investigated at the genetic level. Deletion of the mobile genetic elements known as spoVA2mob reduces heat resistance in $B$. licheniformis, $B$. subtilis and $B$. amyloliquefaciens strains, whereas insertion has been reported to improve heat resistance (Soni et al., 2016).

A summary of the resistance properties of a spore is as follows. Many factors determine the resistance properties of a spore against heat, chemical and physical treatment, including its thick proteinaceous coat, low water content, and high levels of DPA and divalent cations in the spore core.

\section{Physical inactivation methods for Bacillus spores}

\section{Conventional heat processing}

Appert (1810) demonstrated that the heating food in sealed container could keep shelf stable for long periods at room temperature, and Bigelow et al. (1920) made the first mathematical model related to thermal processing as loglinear spore inactivation kinetics (Gould, 2006; Leuschner and Lillford, 2003).

Bacillus species with endospores are present in various spicy vegetables such as garlic, ginger, and onion. High- 


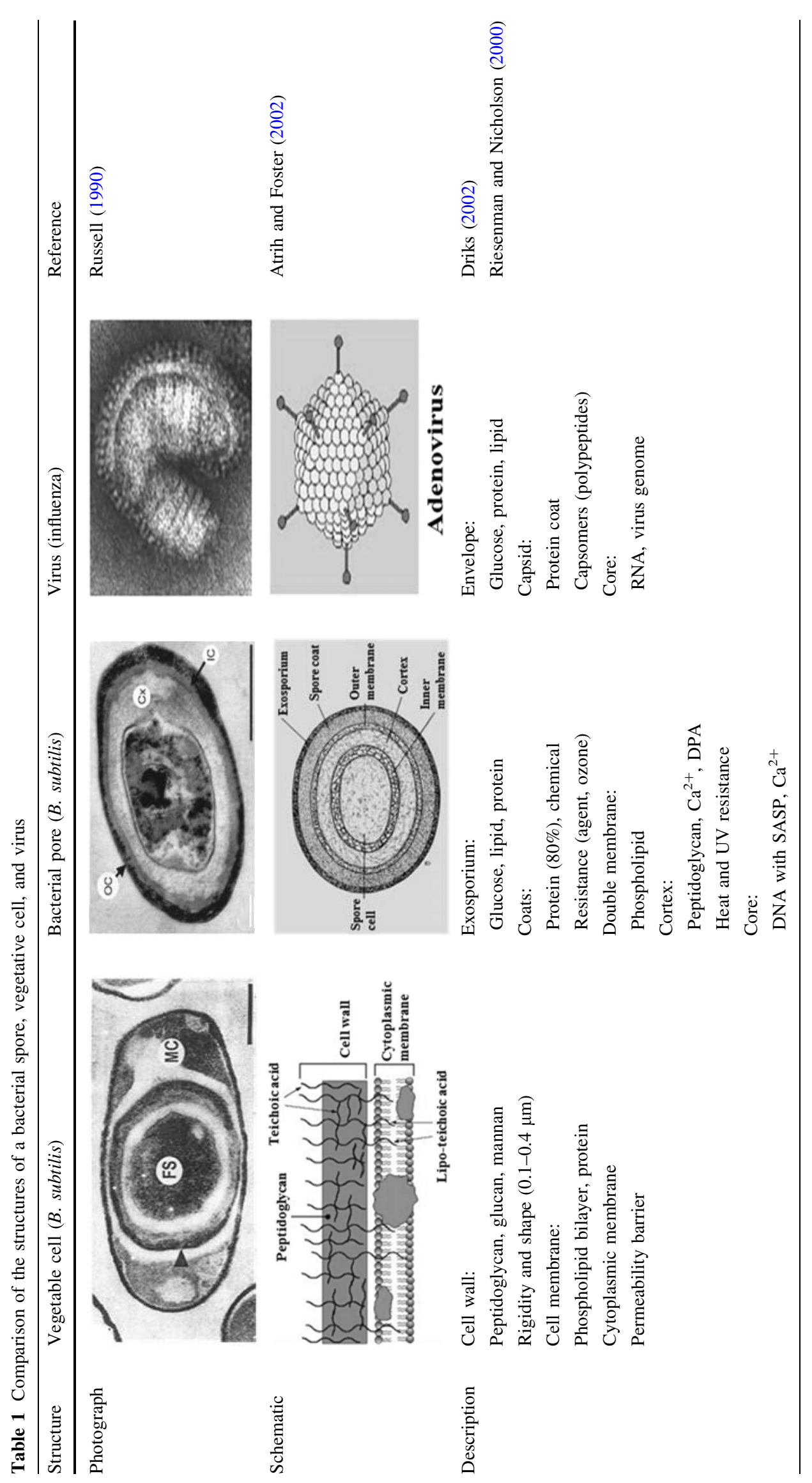


temperature treatment in a retort can be used to sterilize heat-resistant spores. Bacillus species are often present in raw milk and play an important role in the spoilage of milk and milk-based products, and the use of ultra-high-temperature (UHT) processing can inactivate intact spores so as to achieve a long shelf life at room temperature (Atrih and Foster, 2002; Crielly et al., 1994; Gould, 2006).

Heat-resistant microorganisms such as B. subtilis spores derived from the soil may be present in soy milk, and conventional long-term high-temperature treatment of soy milk provides sufficient inactivation for these spores. However, heating processes involving retort and UHT negatively affect taste, color and texture quality due to protein denaturation and decomposition of nutrients at high temperatures of $121-135{ }^{\circ} \mathrm{C}$ (Crielly et al., 1994; Leuschner and Lillford, 2003).

The mechanism of resistance of spores to wet heat is unknown, but can be multicomponent, such as spore protoplasts with low levels of water. In addition, mineralization of spores contributes to heat resistance as does calcium DPA. Contrary to a lack of understanding of the mechanism of wet heat resistance, small DNA-binding acid-soluble proteins are a major cause of dry heat resistance (Atrih and Foster, 2002; Crielly et al., 1994; Leuschner and Lillford, 2003).

\section{Novel heat processing}

The ohmic heating based on electric resistance heating was reportedly used to inactivate micro-organisms in milk in 1919 (Anderson and Finkelstein, 1919). Today, various studies using low frequency alternating current of $500 \mathrm{~Hz}-$ $20 \mathrm{kHz}$ instead of commercial alternating current of $50-60 \mathrm{~Hz}$ were carried out and conditions that can be applied to some products such as paste sauce and fish cake have been established. Ohmic heating with low frequency alternating current is useful because of the increased stability and energy efficiency (Uemura et al., 2010).

Until recently, ohmic heating was generally thought to kill microorganisms through the thermal effect of uniform and rapid heat generation. However, more and more evidence suggests that non-thermal effects may occur (Somavat et al., 2012). Ohmic treatments at frequencies of $60 \mathrm{~Hz}$ and $10 \mathrm{kHz}$ were compared with conventional heating at 121,125 and $130{ }^{\circ} \mathrm{C}$ for four different holding times. Both ohmic treatments showed a general trend of accelerated Geobacillus stearothermophilus spore inactivation. It is assumed that under high temperature conditions, electric field oscillations of polar dipicolinic acid molecules (DPA) and spore proteins can lead to accelerated inactivation. However, there is very little literature on the specific non-thermal effect of electricity on bacterial spores during ohmic heating. Efficient biological verification of ohmic heating to realize the full potential of the process requires new analytical and interpretation methods. If there is a non-thermal effect of electricity on ohmic heating, it can potentially improve quality by reducing process severity (Somavat et al., 2012).

Uemura et al. (2010) studied the effect of inactivation of B. subtilis spores in soymilk with radio-frequency heating (Uemura et al., 2010). When processing soymilk at a frequency of $28 \mathrm{MHz}$, the following results were obtained. Radio-frequency heating processing reduced $B$. subtilis spores in soybean milk by four-logarithmic orders at an outlet temperature of $115^{\circ} \mathrm{C}$. When processing soymilk, the Teflon film covering the electrode effectively prevented scaling. Tofu made with radio-frequency heated soymilk had a higher breaking strength than tofu made with conventional heated soy milk. It was concluded that radiofrequency heating could be used to improve soybean safety and tofu quality (Uemura et al., 2010).

\section{Non-thermal inactivation processing}

Recent attention has been focused on nonthermal microbial inactivation methods that are based on various types of physical energy such as high pressures, ultrasound, highvoltage electric fields, and cold plasma for inactivating food-borne enteropathogenic bacteria and spoilage fungi related to the deterioration of quality and safety (Cho et al., 1999; Hayakawa et al., 1998; Marquez et al., 1997; Mendes-Oliveira et al., 2019).

However, endospore-forming bacteria such as $B$. subtilis exhibit resistance to physical treatments. Many new methods have been studied recently for the purpose of overcoming the resistance of some spores to the nonthermal inactivation methods (Table 2) (Cho et al., 1999; Hayakawa et al., 1998; Marquez et al., 1997; Moreau et al., 2000; Sawai et al., 1997; Vaid and Bishop, 1998; Warrimer et al., 2000). One study investigated the killing of bacterial spores using a high-voltage pulsed electric field (HVPEF) (Marquez et al., 1997). The results indicated that Bacillus spores were damaged when the electric field strength was $\geq 35 \mathrm{kV} / \mathrm{cm}$. The basic mechanism of inactivation of spores was explained by pulse polarity, and ions in the spore cortex would become a shielding layer that prevented radiation from penetrating the core, and the cortex was destroyed by ionic interfacial polarization; however, the exact mechanism was not clear (Marquez et al., 1997). In another study, a method associated with concentrated highintensity electric field (CHIEF) developed by the University of Minnesota has considerable potential as a commercial process for non-thermal pasteurization of fresh liquid foods (Deng et al., 2013). The average ( \pm standard deviation) of microbial inactivation after subjecting milk samples to a single pass through CHIEF was $2.95( \pm 0.35)$, 
Table 2 Summary of novel physical methods for the inactivation of $B$. subtilis spores

\begin{tabular}{|c|c|c|c|c|c|}
\hline Method & & Mechanism & $\begin{array}{l}\text { Effect on } B \text {. } \\
\text { subtilis spores }\end{array}$ & Equipment & References \\
\hline \multirow[t]{3}{*}{ Indirect } & $\begin{array}{l}\text { 1. Far-infrared } \\
\text { irradiation }\end{array}$ & Rapid heat activation of spores & $\begin{array}{l}\text { Increased } \\
\text { germination }\end{array}$ & $\begin{array}{l}\text { Irradiation } \\
\text { system }\end{array}$ & $\begin{array}{l}\text { Sawai } \\
\text { et al. } \\
\text { (1997) }\end{array}$ \\
\hline & 2. Ohmic heating & $\begin{array}{l}\text { Tyndallization (spore germination) increased } \\
\text { by applying an electric current }\end{array}$ & \multirow[t]{2}{*}{$\begin{array}{l}\text { Increased } \\
\text { germination }\end{array}$} & Ohmic heater & $\begin{array}{l}\text { Cho et al. } \\
\text { (1999) }\end{array}$ \\
\hline & 3. Microwave irradiation & $\begin{array}{l}\text { Explosion of internal pressure generated } \\
\text { within the core }\end{array}$ & & $\begin{array}{l}\text { MDS-2100 } \\
\text { microwave } \\
\text { generator }\end{array}$ & $\begin{array}{c}\text { Vaid and } \\
\text { Bishop } \\
\text { (1998) }\end{array}$ \\
\hline Indirect + direct & $\begin{array}{l}\text { 4. High-voltage pulsed } \\
\text { electric field }\end{array}$ & $\begin{array}{l}\text { 1. Cortex destruction by pulse polarity } \\
\text { 2. Rapid germination of spores }\end{array}$ & $\begin{array}{l}10^{1}-10^{3} \\
\text { inactivation }\end{array}$ & $\begin{array}{l}\text { HVPEF system } \\
\quad(50 \mathrm{kV} / \mathrm{cm})\end{array}$ & $\begin{array}{l}\text { Marquez } \\
\text { et al. } \\
\text { (1997) }\end{array}$ \\
\hline \multirow[t]{5}{*}{ Direct } & $\begin{array}{l}\text { 5. UV excimer laser } \\
\text { irradiation }\end{array}$ & Core DNA disruption & $\begin{array}{l}10^{4}-10^{6} \\
\text { inactivation }\end{array}$ & $\begin{array}{l}\text { KrF excimer } \\
\text { laser }\end{array}$ & $\begin{array}{l}\text { Warrimer } \\
\text { et al. } \\
(2000)\end{array}$ \\
\hline & 6. & $\begin{array}{l}\text { 1. Cavitation mechanical stress } \\
\text { 2. } \mathrm{H} \text { - and } \mathrm{OH} \text { - free radicals }\end{array}$ & $\begin{array}{l}10^{1}-10^{3} \\
\text { inactivation }\end{array}$ & Resistometer & $\begin{array}{l}\text { Sagong } \\
\text { et al. } \\
\text { (2013) }\end{array}$ \\
\hline & $\begin{array}{l}\text { 7. High-frequency } \\
\text { ultrasound }\end{array}$ & $\begin{array}{l}\text { Imperceptible damage to the spore coat (e.g., } \\
\text { "pinholes") }\end{array}$ & $\begin{array}{l}10^{2} \text { inactivation } \\
(\text { B. globigii })\end{array}$ & $\begin{array}{r}\text { Ultrasound } \\
\text { disruptor }\end{array}$ & $\begin{array}{l}\text { Sagong } \\
\text { et al. } \\
(2013)\end{array}$ \\
\hline & $\begin{array}{l}\text { 8. Flowing afterglow of } \\
\text { plasma }\end{array}$ & $\begin{array}{l}\text { Break bonds in the coat materials and damage } \\
\text { the DNA helices, slow combustion of the } \\
\text { spore material }\end{array}$ & $\begin{array}{l}10^{6} \text { inactivation } \\
\left(50{ }^{\circ} \mathrm{C} \text { for }\right. \\
40 \mathrm{~min})\end{array}$ & $\begin{array}{l}\text { Plasma sterilizer } \\
\text { with MW } \\
\text { afterglow }\end{array}$ & $\begin{array}{l}\text { Moreau } \\
\text { et al. } \\
(2000)\end{array}$ \\
\hline & $\begin{array}{l}\text { 9. Rapid decompression } \\
\text { from a high pressure }\end{array}$ & $\begin{array}{l}\text { Physical breakdown of spore coat increases } \\
\text { the permeability to water }\end{array}$ & $\begin{array}{l}10^{3}-10^{4} \\
\text { inactivation }\end{array}$ & $\begin{array}{l}\text { Link-Motion } \\
\text { System, E.G. } \\
\text { seal MT }\end{array}$ & $\begin{array}{l}\text { Hayakawa } \\
\text { et al. } \\
\text { (1998) }\end{array}$ \\
\hline
\end{tabular}

$2.75( \pm 0.25)$, and $0.18( \pm 0.15) \log \mathrm{CFU} / \mathrm{ml}$ for Salmonella, L. monocytogenes and spore of B. cereus, respectively. The inactivation effect of single pass treatment for Bacillus spores was less, but additional passes are expected to result in more bacterial reduction (Deng et al., 2013).

Hayakawa et al. (1998) reported the use of rapid decompression to inactivate heat-tolerant spores of B. stearothermophilus IFO 12550. Below $400 \mathrm{MPa}$, heatresistant spores such as $B$. stearothermophilus could not be sterilized using a simple pressing method (Amador-Espejo et al., 2014; Hayakawa et al., 1998). However, when $200 \mathrm{MPa}$ pressure was applied at $75^{\circ} \mathrm{C}$ for $60 \mathrm{~min}$, the spore killing rate was $4 \log \mathrm{CFU} / \mathrm{ml}$. This inactivation process increased permeability to water at high pressure and high temperature due to the physical destruction of the spore coat (Amador-Espejo et al., 2014; Hayakawa et al., 1998).

UV irradiation is effective at killing spore forming bacteria that contaminate the surface of various substances. It has been established that the inactivation of cells by UV irradiation is mainly due to the fatal effect on DNA. Exposure to UV radiation can cause a number of detrimental effects such as abnormal ion flow, increased cell membrane permeability and depolarization of the cell membrane (Cho et al., 2012; Gayán et al. 2013; Sun et al., 2016). $\mathrm{UV}_{254}$ showed the strongest inactivation effect, the level of B. subtilis spores decreased by about 3.6-log cycle after $3 \mathrm{~min}$ of exposure, and 2.5-log reduction in spores after 3 min when exposed to $U_{185}$ (Cho et al., 2012).

The intense pulsed light (IPL) is one of the non-thermal treatment technologies that applies intense, short-term light pulses to the food surface. The spectrum used by IPL is similar to sunlight (170-2600 nm), but the intensity of light is 20,000 times stronger. This light can be applied to food surfaces or packaging materials to effectively kill microorganisms with a 3-6 log reduction in Bacillus spores. Although the mechanism of inactivation of IPL has not been fully elucidated, it is generally accepted that the main lethal action of IPL can be attributed to photothermal and/or photochemical mechanisms associated with chemical modification and DNA cleavage (Anderson et al., 2000; Cho et al., 2012; Setlow, 2006). 


\section{Chemical inactivation methods for Bacillus spores}

\section{Chemical sporicidal agents}

Thermal processing of food is a widespread, effective and relatively inexpensive method to prevent for damaging food by decaying microorganisms and undesirable enzymatic reactions. However, heat treatment can reduce nutrient content, modify organoleptic qualities such as fresh, and limit the type of package material available to withstand high processing temperatures. For this reason, alternative processes are being developed using chemicals to minimal changes to the fresh properties of food (Brantne et al., 2014; Kim et al., 1999; Sagripanti and Bonifacino, 1996).

The basic mechanism of the sporicidal action of chemical agents is not well known, mainly due to the complex nature of bacterial spores. The spore surface is hydrophobic, and the complete spore presents several sites at which interaction with chemical agents is possible, such as the inner and outer spore coats, the cortex, spore membranes, and the core (Brantne et al., 2014; Kim et al., 1999; Stragier and Losick, 1996). In addition, the complex structure and composition of spores plays an important role in chemical resistance. The spore has a structure very different from a cell in growth with a number of features and components of the original spores (Kim et al., 1999; Russell, 1990; Sagripanti and Bonifacino, 1996).

Comparatively few antimicrobial agents are actively sporicidal. Even quite powerful bactericides may inhibit spore germination, outgrowth, or both processes; that is, be sporostatic rather than sporicidal (Table 3) (Banksm et al., 1988; Chaibi et al., 1996; Heo and Cho, 2002; Kida et al., 2003; Ko and Kim, 2004; Russell, 1990; Sagripanti and Bonifacino, 1996). The most important chemical sporicides are glutaraldehyde, formaldehyde (both liquid and vapor forms), chorine-releasing agents, peroxygens, ethylene oxide, and ozone (Table 3) (Banksm et al., 1988; Chaibi et al., 1996; Heo and Cho, 2002; Kida et al., 2003; Ko and Kim, 2004; Russell, 1990; Sagripanti and Bonifacino, 1996). Sporicidal treatment always takes considerably longer than treatment for vegetative cells and requires higher concentrations when chemicals are involved.

Some food-grade antimicrobial agents such as protamine, polylysine, sodium lactate, poly fatty acid ester, essential oils and organic acids exhibit sporostatic and sporicidal activities (Chaibi et al., 1996; Heo and Cho, 2002; Kim et al., 1999; Sagripanti and Bonifacino, 1996). Protamine extracted from the spermary of fish inhibits the functions of peptidoglycan, DNA, RNA, protein synthesis, and ATP related to spore growth (Kida et al., 2003; Kim et al., 1999). Inactivation of spores by protamine improves when combined with heat treatment (Kida et al., 2003; Kim et al., 1999). Polylysine exerts an inhibitory effect on spore germination through its surfactant function (Heo and Cho, 2002; Ko and Kim, 2004). And sodium lactate, glycine, lysolecithin, poly fatty acid ester, L-phenylalanine, essential oils, and L-serine can inhibit the growth of spores due to binding between the polar groups in the spore coat and the hydrophobic groups of surfactant components (Oscroft et al., 1990; Ruth, 2001; Setlow et al., 2002a; 2002b). Organic acids such as lactic acid are best suited for the development of novel antibacterial substances for inactivating $B$. subtilis spores. The killing effect of organic acids such as lactic acid, citric acid and acetic acid on intact spores at low $\mathrm{pH}$ conditions was considered to be due to unstable growth environments by changes in ionic composition (Oscroft et al., 1990; Ruth, 2001; Setlow et al., 2002a; 2002b).

\section{Sporicidal agents of plant original}

Some chemical food preservatives have a long history of safe use, but there are reports that sensitive individuals sometimes develop allergic reactions and can produce carcinogenic byproducts. This has raised concerns about the harmful effects that preservatives can have on health. This has led to a revival of interest in antibacterial compounds of plant origin.

More than 1300 plants are known as potential sources of antibacterial agents. Antibacterial plants that could be used as preservatives can be divided into several different categories, including phenolics, polyphenol, guinones, flavones, flavonoids, flavonols, tannins, coumarins, terpenoids, alkaloids, lectins, and polypeptides. Many plant-derived antimicrobial compounds exhibit a wide spectrum of activity against bacteria, which has led to suggestions that they could be used as natural preservatives in foods (Kim et al., 1999; Kim and Shin, 1997; Nishina et al., 1995). The tannin, polyphenol, theaflavin and catechin in tea extract, and caffeic acid were effective inhibitors of the germination of Bacillus spores (Kim and Shin, 1997; Nishina et al., 1995). Germination inhibition was presumed to result from the effects of eugenol, thymol, citral, cinnamaldehyde, camphor, limonene, carvone, cymene, and capsaicin, but the underlying inhibitory mechanism was not adequately described (An et al., 1999; Chaibi et al., 1996; 1997; Choi et al., 1997).

Many surfactants with hydrophilic and hydrophobic properties can inactivate various types of Bacillus spores. The crude extracts of Torilis japonica, Gardenia jasminoides, Plantago asiatica, Fritillaria species, and Arctium lappa with surfactant components showed particularly high sporicidal activities, reducing spore counts by about $2 \log$ CFU/ml (Cho et al., 2015; Kim et al., 1999; Setlow et al., 
Table 3 Agents exhibiting bactericidal and sporicidal activities

\begin{tabular}{|c|c|c|c|c|}
\hline Antibacterial agents & $\begin{array}{l}\text { Sporicidal concentration } \\
(\% \mathrm{wt} / \mathrm{vol})\end{array}$ & $\begin{array}{l}\text { Structures } \\
\text { targeted }\end{array}$ & Comment & References \\
\hline Chlorocresol & $>0.4$ & Cortex & & Russell (1990) \\
\hline Cresol & $>0.5$ & & & Russell (1990) \\
\hline Phenol & $>5.0$ & & & Russell (1990) \\
\hline $\begin{array}{l}\text { Phenylmercuric } \\
\text { nitrate }\end{array}$ & $>0.02$ & & & $\begin{array}{l}\text { Sagripanti and Bonifacino } \\
\text { (1996) }\end{array}$ \\
\hline $\begin{array}{l}\text { Chlorhexidine } \\
\text { diacetate }\end{array}$ & $>0.05^{\mathrm{a}}$ & Cortex & $\begin{array}{l}\text { UDS }^{\mathrm{b}} \text { spores more sensitive than } \\
\text { "normal" spores }\end{array}$ & $\begin{array}{l}\text { Sagripanti and Bonifacino } \\
\text { (1996) }\end{array}$ \\
\hline $\begin{array}{l}\text { Cetylpyridinium } \\
\text { chloride }\end{array}$ & $>0.05^{\mathrm{a}}$ & Cortex & & Russell (1990) \\
\hline Glutaraldehyde & 2.0 & Cortex & UDS $^{\mathrm{b}}$ spores highly sensitive & $\begin{array}{l}\text { Sagripanti and Bonifacino } \\
\text { (1996) }\end{array}$ \\
\hline Formaldehyde & $4-8$ & & & Russell (1990) \\
\hline Hydrogen peroxide & & Core & Varies with species & Russell (1990) \\
\hline Hypochlorite & $20 \mathrm{ppm}$ & Cortex & USD $^{\mathrm{b}}$ spores highly sensitive & $\begin{array}{l}\text { Sagripanti and Bonifacino } \\
\text { (1996) }\end{array}$ \\
\hline Polylysine & 0.5 & Coat, Cortex & & Heo and Cho (2002) \\
\hline Lysozyme & & Cortex & UDS $^{\mathrm{b}}$ spores highly sensitive & Kida et al. (2003) \\
\hline Sodium lactate & & & & Banksm et al. (1988) \\
\hline Poly fatty acid ester & & & & Chaibi et al. (1996) \\
\hline Protamine & & Core & & Kida et al. (2003) \\
\hline $\begin{array}{l}\text { Thiamine } \\
\text { dilaurylsulfate }\end{array}$ & 1.0 & Coat, Cortex & & Kida et al. (2003) \\
\hline Nisin & & Core & & Kida et al. (2003) \\
\hline Ethanol & & Core & & Ko and Kim (2004) \\
\hline
\end{tabular}

*It means that exhibiting bactericidal and sporicidal activities of the chemical agents can be affected by $\mathrm{pH}$, temperature and treatment time in sterilization of Bacillus spores

${ }^{a}$ Not sporicidal at this concentration at ambient temperatures

${ }^{\mathrm{b}}$ UDS (Urea + Dithiothreitol + Sodium lauryl sulfate at alkaline $\mathrm{pH}$ ) : the treatment of UDS were used for achieving such spores with solubilizing of coat proteins

2000). In addition, the decreasing of $1-2 \log \mathrm{CFU} / \mathrm{ml}$ on the number of spores was achieved by treating each surfactant component such as $1 \%(\mathrm{w} / \mathrm{w})$ concentration bornyl acetate, geranyl acetate, pinene, p-cymene, camphene, citral, 2,3-dihydrobenzofuran, polylysine and thiamine dilaurylsulfate (Table 4) (An et al., 1999; Chaibi et al., 1997; Cho et al., 2015; Choi et al., 1997). It has also been found that hydrophobic surfactants were more effective at killing B. subtilis spores than hydrophilic surfactants. Furthermore, the sporicidal effects of surfactants such as geranyl acetate and c-terpinene were found to be significantly enhanced in the presence of a germinant, because Lalanine and synergistic cofactors (e.g., $\mathrm{K}$ ions) trigger cortex hydrolysis in spores (Cho et al., 2015; Gould, 2006; Russell, 1990).

In addition, the method of chemical inactivation using synthetic preservatives is expected to decrease gradually, taking into account the tendency of consumers' health preferences. Therefore, there is a need for research on a method for sterilizing Bacillus spores related to pathogenicity and quality damage using natural anmicrobial agents. In addition, various studies on effective environmentally friendly physical methods using electricity, pressure, and light energy that can replace chemical inactivation are important.

\section{Inactivation by combination of physical and chemical methods}

\section{Inactivation using combination of physical energy}

Consumers' demands for safe foods with good taste and high nutritional value are increasing. Innovative thermal and non-thermal methods associated with microbial inactivation are alternatives to preparing safe foods that are fresh and minimally processed. Combining physical methods based on various types of energy is more effective 
Table 4 Various surfactant components exhibiting sporicidal activity against B. subtilis spores

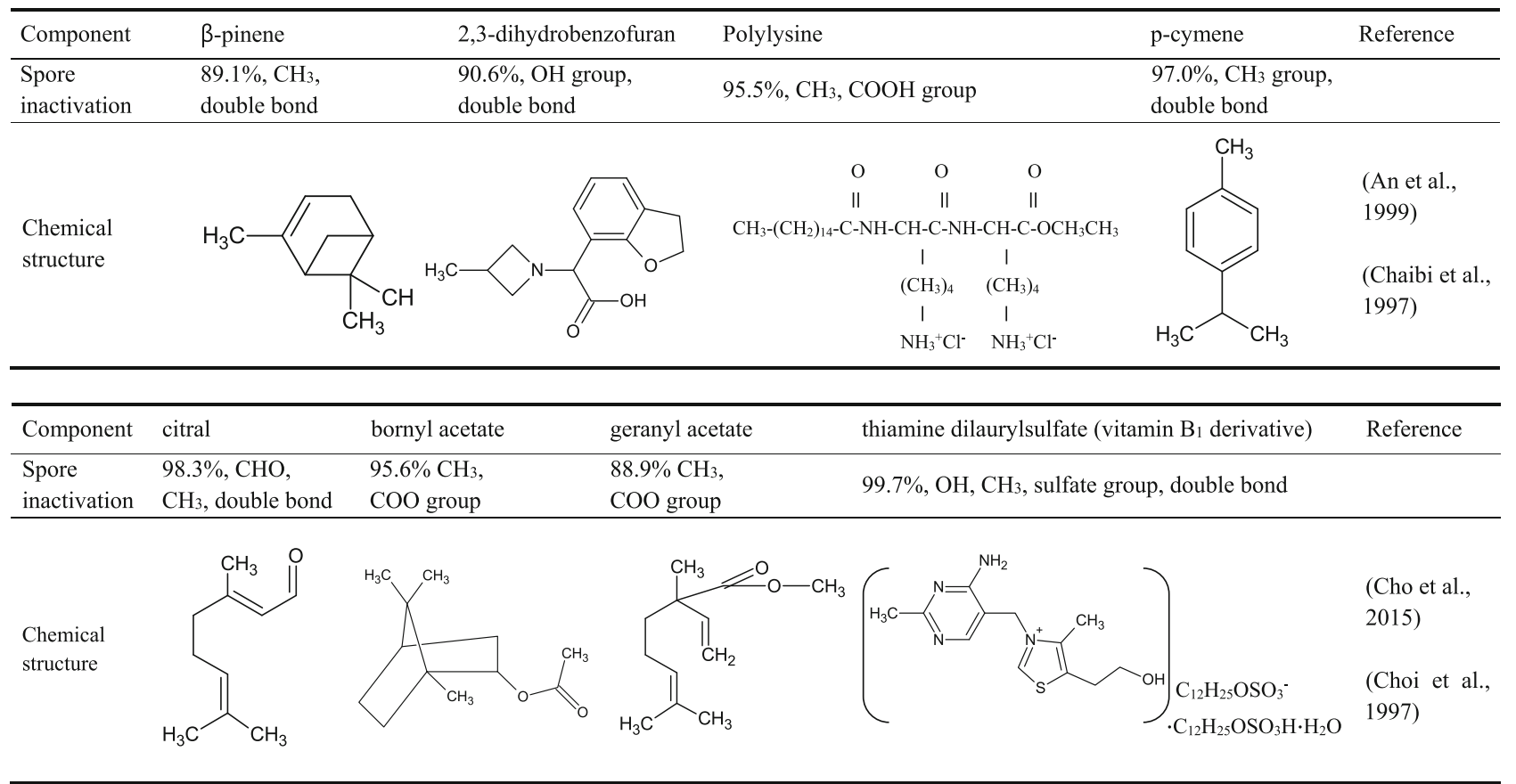

than applying a single energy type for inactivation of Bacillus spores.

The efficacy of ultrasound treatment is often increased by combining it with other physical or chemical lethal factors that help to shorten the treatment time and improve quality retention. The inactivation of $B$. subtilis spores by ultrasound waves under pressure (manosonication [MS]) and by combined mild heating and MS treatment (manothermosonication) has been studied (Raso et al., 1998; Sagong et al., 2013). Combining heating at 70-90 ${ }^{\circ} \mathrm{C}$ with MS treatment at $20 \mathrm{kHz}, 300 \mathrm{kPa}$, and $117 \mu \mathrm{m}$ for $6 \mathrm{~min}$ had a synergistic effect on spore inactivation as $90-99.9 \%$ disruption for $B$. subtilis spores. The results suggested that the mechanical effects of ultrasound were probably responsible for the damage to Bacillus spores and the associated loss of viability (Raso et al., 1998; Sagong et al., 2013).

In addition, combined pressure and ohmic heating sterilization is a new technology developed by Ohio State University to preserve food while maintaining the quality properties desired by consumers (Park et al., 2013). The pressure-ohmic-thermal sterilization (POTS) for Bacillus spores was treated at $50 \mathrm{~V} / \mathrm{cm}, 600 \mathrm{MPa}$ and $105{ }^{\circ} \mathrm{C}$ using a laboratory-scale high-pressure processor. B. amyloliquefaciens spores suspended in $0.1 \% \mathrm{NaCl}$ solution $(\mathrm{pH} 7.0$ ) were inactivated by $4.6 \log$ for a retention time of $30 \mathrm{~min}$ (Park et al., 2013).
The result of invesgating for a case study on a inactivation method for Bacillus spore by combines of pulsed electric field (PEF) and heating, a 5-log inactivation of $B$. subtilis spores in milk has been reported to attain by preheating the milk to $95{ }^{\circ} \mathrm{C}$, followed by an increase of temperature to $120{ }^{\circ} \mathrm{C}$ by PEF $(130 \mathrm{~kJ} / \mathrm{kg}$ ) treatment (Soni et al. 2016). And a 3-log reduction of $B$. cereus spores was achieved with a field strength of $35 \mathrm{kV} / \mathrm{cm}$ combined with heat treatment $\left(50{ }^{\circ} \mathrm{C}\right)$ in skim milk and a 6-log reduction was observed at $65-75^{\circ} \mathrm{C}$.

Recently, studies on the inactivation of Bacillus spores using superheated steam have been conducted. Specifically, superheated steam (SHS) was used alone or combined with UV-C irradiation for inactivation of $B$. cereus spores inoculated on stainless steel coupons. In order to effectively inactivate $B$. cereus spores only with SHS treatment, a temperature higher than $250{ }^{\circ} \mathrm{C}$ was required, but a synergistic bactericidal effect occurred due to sequential treatment of SHS before or after UV-C irradiation (Kim et al., 2020).

Microwave sterilization was performed to inactivate the spores of biofilms of Bacillus cereus. Complete inactivation based on cell membrane destruction by microwaves was achieved within $5 \mathrm{~min}$, and the efficiency of inactivation by microwaves was clearly higher than that by conventional steam autoclaves (Park et al., 2017). 
Recently, as a new attempt to sterilize Bacillus spores related to foodborne illness and food deterioration using microwave heating or superheated steam has been studied and related commercial facilities have been commercialized and applied in production sites. As such, for commercial development of effective sterilization methods for Bacillus spores, research into non-thermal sterilization that combines electrical, physical and optical energy to minimize quality damage by heat is expected to continue.

\section{Inactivation using combination of physical and chemical treatments}

In addition to the above methods, combining various physical preservation methods such as UV irradiation with antibacterial agents such as surfactant components may have a synergistic effect on Bacillus spore inactivation (Choi et al., 1997; Elmnasser et al., 2007). The energy required from UV irradiation to inactivate the $B$. subtilis spores was $50 \%$ lower in the presence of $1 \%$ ethanol extract of $T$. japonica fruit than with UV irradiation alone. Besides, the $\mathrm{LD}_{90}$ value, which is the inactivation time to reduce $90 \%$ of microorganisms, on the inactivation of the intact Bacillus spores shows about 50\% decrease in the value, from $0.60 \mathrm{~min}$ at $\mathrm{UV}$ irradiation alone to $0.32 \mathrm{~min}$ at the combined treatment (Cho et al., 2012; Setlow, 2006).

And some studies have shown synergistic inactivation effects of combined PEF with antibacterial chemical extracts such as essential oils, polyphenols against Bacillus spores. B. subtilis spores was seen with cardamom oil that led to a 3.12-log reduction, and the addition of nisin prior to PEF treatment on B. cereus spores in skim milk resulted in a 3-log reduction (Soni et al. 2016).

The combined treatment of physical energy such as heating, high pressure, ultrasound, electric energy, ultraviolet, intense pulsed light and chemical agents such as natural antimicrobial agents with surfactant components can act synergistically and effectively to kill spores. And also, can be a potential non-thermal method on microbial inactivation in various food industry.

As such, research on non-thermal sterilization that combines high intensity electrical, physical and light energy minimizing the quality damage by heating for commercial development of effective sterilization methods for Bacillus spores related to foodborne illness and food deterioration is expected to continue.

Acknowledgements This work was supported by Basic Science Research Program through the National Research Foundation of Korea (NRF) funded by the Ministry of Education (NRF2019R1A2C1085100).

\section{Compliance with ethical standards}

Conflict of interest The authors declare that they have no conflict of interest.

Open Access This article is licensed under a Creative Commons Attribution 4.0 International License, which permits use, sharing, adaptation, distribution and reproduction in any medium or format, as long as you give appropriate credit to the original author(s) and the source, provide a link to the Creative Commons licence, and indicate if changes were made. The images or other third party material in this article are included in the article's Creative Commons licence, unless indicated otherwise in a credit line to the material. If material is not included in the article's Creative Commons licence and your intended use is not permitted by statutory regulation or exceeds the permitted use, you will need to obtain permission directly from the copyright holder. To view a copy of this licence, visit http://creativecommons. org/licenses/by/4.0/.

\section{References}

Ablett S, Dark AH, Lillford PJ, Martin DR. Glass formation and dormancy in bacterial spores. Int. J. Food Sci. Technol. 34: 59-69 (1999)

Amador-Espejo GG, Hernández-Herrero MM, Juan B, Trujillo AJ. Inactivation of Bacillus spores inoculated in milk by ultra high pressure homogenization. Food Microbiol. 44: 204-210 (2014)

An BJ, Son AR, Lee JT. Studies on the antimicrobial activity of extracts of Korean medicinal plants. J. Life Res. Ind. 4: 46-58 (1999)

Anderson AK, Finkelstein R. A study of the electro pure process of treating milk. J. Dairy Sci. 2: 374-406 (1919)

Anderson JG, Rowan NJ, MacGregor SJ, Fouracre RA, Farish O. Inactivation of food-borne enteropathogenic bacteria and spoilage fungi using pulsed-light. IEEE T. Plasma Sci. 2: 83-88 (2000)

Atrih A, Foster SJ. Bacterial endospores the ultimate survivors. Int. Dairy J. 12: 217-223 (2002)

Banksm JG, Morgan S, Stringer MF. Inhibition of heated Bacillus spores by combinations of potassium sorbate, sodium benzoate, $\mathrm{pH}$ and organic acids. Lebenson. Wiss. Technol. 21: 250-255 (1988)

Bigelow WD, Bohart GS, Richardson AC, Ball CO. Heat penetration in processing canned foods. Bulletin No. 16-L. Washington DC: National Canners Association. (1920)

Brantne CA, Hannah RM, Burans JP, Pope RK. Inactivation and ultrastructure analysis of Bacillus spp. and Clostridium perfringens spores. Microsc. Microanal. 20: 238-244 (2014)

Chaibi A, Ababouch LH, Belasri K, Boucetta S, Busta FF. Inhibition of germination and vegetative growth of Bacillus cereus $\mathrm{T}$ and Clostridium botulinum 62A spores by essential oils. Food Microbiol. 14: 161-174 (1997)

Chaibi A, Ababouch LH, Busta FF. Inhibition of bacterial spores and vegetative cells by glycerides. J. Food Prot. 59: 716-722 (1996)

Cho HY, Yousef AE, Sastry SK. Kinetics of inactivation of Bacillus subtilis spores by continuous or intermittent ohmic and conventional heating. Biotechnol. Bioeng. 62: 368-372 (1999)

Choi MY, Choi EJ, Lee E, Park HJ. Antimicrobial activities of pine needle (pinus densiflora Seib et Zucc.) extract. Korean J. Microbiol. 25: 293-297 (1997)

Cho WI, Cheigh CI, Chung MS, Park KH, Chang PS, Chung MS. The combined effect of UV irradiation and ethanol extract from Torilis japonica fruit on inactivation of Bacillus subtilis spores. J. Food Saf. 32: 474-480 (2012) 
Cho WI, Cheigh CI, Hwang HJ, Chung MS. Sporicidal activities of various surfactant components against Bacillus subtilis spores. J. Food Prot. 78: 1221-1225 (2015)

Crielly EM, Logan NA, Anderton A. Studies on the Bacillus flora of milk and milk products. J. Appl. Microbiol. 77: 256-263 (1994)

de Hoon MJ. Eichenberger P, Vitkup D. Hierarchical evolution of the bacterial sporulation network. Curr. Biol. 20: 735-745 (2010)

Deng S, Chen P, Li Y, Ma X, Cheng Y, Lin X, Metzger L, Ruan R. Non-thermal pasteurization of milk using CHIEF technology in Emerging dairy processing technologies: Opportunities for the dairy industry. edited by N. Datta, John Wiley \& Sons, Limited. (2013)

Driks A. Bacillus subtilis spore coat. Microbiol. Mol. Biol. Rev. 63: 1-20 (1999)

Driks A. Overview: Development in bacteria; spore formation in Bacillus subtilis. Cell. Mol. Life Sci. 59: 389-391 (2002)

Elmnasser N, Guillou S, Leroi F, Orange N, Bakhrouf A, Federighi, M. Pulsed-light system as a novel food decontamination technology: a review. Can. J. Microbiol. 53: 813-821 (2007)

Fitz-James PC. Participation of the cytoplasmic membrane in the growth and spore formation of bacilli. J. Bio-phys. Biochem. Cytol. 8: 507-508 (1960)

Foster SJ, Johnstone K. Pulling the trigger, the mechanism of bacterial spore germination. Mol. Microbiol. 4: 137-141 (1990)

Gayán E, Álvarez I, Condón S. Inactivation of bacterial spores by UV-C light. Innov. Food Sci. Emerg. Technol. 19: 140-145 (2013)

Gould GW. REVIEW ARTICLE History of science - spores Lewis B Perry Memorial Lecture 2005. J. Appl. Microbiol. 101: 507-513 (2006)

Hayakawa I, Furukawa S, Midzunaga A, Horiuchi H, Nakashima T, Fujio Y, Yano Y, Ishikura T, Sasaki K. Mechanism of inactivation of heat-tolerant spores of Bacillus stearothermophilus IFO 12550 by rapid decompression. J. Food Sci. 63: 371-374 (1998)

Heo CY, Cho SH. Antimicrobial activity of polylysine produced by Streptomyces sp. J. Agric. Life Sci. 36: 47-52 (2002)

Higgins D, Dworkin J. Recent progress in Bacillus subtilis sporulation. FEMS Microbiol. Rev. 36: 131-148 (2012)

Hills GM. The effect of amino acids on the germination of Bacillus anthracis with some observations on the relation of optical form to biological activity. Biochem. J. 45: 363-370 (1949)

Irene ST, Kumaran SR. Spore formation in Bacillus subtilis. Environ. Microbiol. Rep. 6: 212-225 (2014)

Jeffrey SR, Baldeck JD, Rutherford GC, Marquis RE. Characterization of UV-peroxide killing of bacterial spores. J. Food Prot. 66: 1233-1240 (2003)

Kida N, Mochizuki Y, Taguchi F. An effective sporicidal reagent against Bacillus subtilis spores. Microbiol. Immunol. 47: 279-283 (2003)

Kim HS, Shin JO. Isolation and antimicrobial activity of Xanthium strumarium L. extact. Korean J. Microbiol. Biotechnol. 25: 183-188 (1997)

Kim HY, Lee YJ, Kim SH, Hong KH, Kwon YK, Lee JY, Ha SC, Cho HY, Chang IS, Lee CW. Studies of the development of natural preservation from natural products. Korean J. Food Sci. Technol. 31: 1667-1678 (1999)

Kim SS, Kim SH, Park SH, Kang DH. Inactivation of Bacillus cereus spores on stainless steel by combined superheated steam and UV-C irradiation treatment. J. Food Prot. 83: 13-16 (2020)

Knaysi G. Cytology of bacteria. Bot. Rev. 4: 83-92 (1938)

Ko EM, Kim BY. Antimicrobial activity of $\varepsilon$-Polylysine mixtures against food-borne pathogens. J. Korean Soc. Food Sci. Nutr. 33: 705-710 (2004)

Leuschner RGK, Lillford PJ. Thermal properties of bacterial spores and biopolymers. Int. J. Food Microbiol. 80: 131-143 (2003)
Marquez VO, Mittal GS, Griffiths MW. Destruction and inhibition of bacterial spores by high voltage pulsed electric field. J. Food Sci. 62: 399-401 (1997)

Meador-Parton J, Popham DL. Structural analysis of Bacillus subtilis spore peptidoglycan during sporulation. J. Bacteriol. 182: 4491-4499 (2000)

Mendes-Oliveira G, Jensen JL, Keener KM, Campanella OH. Modeling the inactivation of Bacillus subtilis spores during cold plasma sterilization. Innov. Food Sci. Emerg. Technol. 52: 334-342 (2019)

Moreau S, Moisan M, Tabrizian M, Barbeau J, Pelletier J, Ricard A, Yahia LH. Using the flowing afterglow of a plasma to inactivate Bacillus subtilis spores: influence of the operating conditions. J. Appl. Phys. 88: 1166-1174 (2000)

Moriyama R. Molecular mechanism of cortex hydrolysis during bacterial spore germination. J. Agr. Chem. Soc. Japan. 72: 1455-1461 (1998)

Nishina A, Tezuka H, Matsunaga M. Inhibition of the development and reduction of heat resistance of bacterial spores by coffee residue extract. Journal of Antibacterial Antifungal Agents. 23: 681-684 (1995)

Oh S, Moon MJ. Inactivation of Bacillus cereus spores by high hydrostatic pressure at different temperature. J. Food Prot. 66: 599-603 (2003)

Oscroft C, A Banks JG, McPhee S. Inhibition of thermally-stressed Bacillus spores by combinations of nisin, $\mathrm{pH}$ and organic acids. Lebenson. Wiss. Technol. 23: 538-544 (1990)

Paidhungat M, Ragkousi K, Setlow P. Genetic requirements for induction of germination of spores of Bacillus subtilis by $\mathrm{Ca}^{2+}$. dipicolinate. J. Bacteriol. 183: 4886-4893 (2001)

Paredes-Sabja D, Setlow P, Sarker MR. Germination of spores of Bacillales and Clostridiales species: mechanism and proteins involved. Trends Microbiol. 19: 85-94 (2011)

Park HS, Yang JW, Choi HJ, Kim KH. J. Effective thermal inactivation of the spores of Bacillus cereus biofilms using microwave. Microbiol. Biotechnol. 27: 1209-1215 (2017)

Park SH, Balasubramaniam VM, Sastry SK, Lee J. Pressure-ohmicthermal sterilization: A feasible approach for the inactivation of Bacillus amyloliquefaciens and Geobacillus stearothermophilus spores. Innov. Food Sci. Emerg. Technol. 19: 115-123 (2013)

Peleg M, Cole MB. Estimating the survival of Clostridium botulinum spores during heat treatments. J. Food Prot. 63: 190-195 (2000)

Raso J, Palop A, Pagan R, Condon S. Inactivation of Bacillus subtilis spores by combining ultrasonic waves under pressure and mild heat treatment. J. Appl. Microbiol. 85: 849-854 (1998)

Riesenman PJ, Nicholson WL. Role of spore coat layers in Bacillus subtilis spore resistance to hydrogen peroxide, artificial UV-C, UV-B, and solar UV radiation. J. Appl. Environ. Microbiol. 66: 620-626 (2000)

Ross C, Abel-Santos E. The Ger receptor family from sporulating bacteria. Curr. Issues Mol. Biol. 12: 147-158 (2010)

Russell AD. Bacterial spores and chemical sporicidal agents. Clin. Microbiol. Rev. 3: 99-119 (1990)

Ruth GH. Combining bicontrol agents to reduce the variability of biological control. Phytopathology. 91: 621-627 (2001)

Ryter A, Schaeffer P, Ionesco H. Classification cytologique, par la stade de blocage des mutants de sporulation de $B$. subtitlis Marburg. Ann. Inst. Pasteur. 110: 305-311 (1966)

Sagong HG, Cheon HL, Kim SO, Lee SY, Park KH, Chung MS, Choi YJ, Kang DH. Combined effects of ultrasound and surfactants to reduce Bacillus cereus spores on lettuce and carrots. Int. J. Food Microbiol. 160: 367-372 (2013)

Sagripanti JL, Bonifacino A. Comparative sporicidal effects of liquid chemical agents. J. Appl. Environ. Microbiol. 62: 545-551 (1996) 
Sandra RBRS, Luciana PSV, Carlos RS. Life cycle and spore resistance of spore-forming Bacillus atrophaeus. Microbiol. Res. 169: 931-939 (2014)

Sawai J, Fujisawa M, Kokugan T, Shimizu M. Pasteurization of bacterial spores in liquid medium by far-infrared irradiation. J. Chem. Eng. Jpn. 30: 170-172 (1997)

Sekiguchi J, Sato T, Nanamiya H, Ohashi Y, Kawamura F, Takamatsu H, Kodama T, Watabe K, Ishikawa S. Formation, structure and germination of the spore of Bacillus subtilis. Protein Nucleic acid Enzyme. 44: 1460-1466 (1999)

Setlow B, Mcginnis KA, Ragkousi K, Setlow P. Effect of major spore-specific DNA binding proteins on Bacillus subtilis sporulation and spore properties. J. Bacteriol. 182: 6906-6912 (2000)

Setlow B, Loshon CA, Genest PC, Cowan AE, Setlow C, Setlow P. Mechanisms of killing spores of Bacillus subtilis by acid, alkali and ethanol. J. Appl. Microbiol. 92: 362-375 (2002a)

Setlow B, Mcginnis KA, Ragkousi K, Setlow P. Effect of major spore-specific DNA binding proteins on Bacillus subtilis sporulation and spore properties. J. Bacteriol. 182: 6906-6912 (2002b)

Setlow B, Setlow P. Small, acid-soluble protein bound to DNA protects Bacillus subtilis spores from killing by dry heat. Appl. Environ. Microbiol. 61: 2787-2790 (1995)

Setlow P. Germination of spores of Bacillus species: what we know and do not know. J. Bacteriol. 196: 1297-1305 (2014)

Setlow P. Spores of Bacillus subtilis: their resistance to and killing by radiation, heat and chemicals. J. Appl. Microbiol. 101: 514-525 (2006)

Somavat R, Mohamed HM, Chung YK, Yousef AE, Sastry SK. Accelerated inactivation of Geobacillus stearothermophilus spores by ohmic heating. J. Food Eng. 108: 69-76 (2012)

Soni A, Oey I, Silcock P, Bremer P. Bacillus spores in the food industry: a review on resistance and response to novel inactivation technologies. Compr. Rev. Food Sci. F. 15: 1139-1148 (2016)
Stragier P, Losick R. Molecular genetics of sporulation in Bacillus subtilis. Annu. Rev. Genet. 30: 297-341 (1996)

Sun P, Tyree C, Huang CH. Inactivation of Escherichia coli, bacteriophage MS2, and Bacillus spores under $\mathrm{UV} / \mathrm{H}_{2} \mathrm{O}_{2}$ and $\mathrm{UV} /$ peroxydisulfate advanced disinfection conditions. Environ. Sci. Technol. 50: 4448-4458 (2016)

Uemura K, Takahashi C, Kobayashi I. Inactivation of Bacillus subtilis spores in soybean milk by radio-frequency flash heating. J. Food Eng. 100: 622-626 (2010)

Vaid A, Bishop AH. The destruction by microwave radiation of bacterial endospores and amplification of the released DNA. J. Appl. Microbiol. 85: 115-122 (1998)

Warrimer K, Rysstad G, Murden A, Rumsby P, Thomas D, Waites WM. Inactivation of Bacillus subtilis spores on packaging surfaces by u.v. excimer laser irradiation. J. Appl. Microbiol. 88: 678-685 (2000)

Zhang JQ, Griffiths KK, Cowan A, Setlow P, Yu J. Expression level of Bacillus subtilis germinant receptor determines the average rate but not the heterogeneity of spore germination. J. Bacteriol. 195: 1735-1740 (2013)

Zhang P, Garner W, Yi X, Yu J, Li Y-G, Setlow P. Factors affecting variability in time between addition of nutrient germinant and rapid dipicolinic acid release during germination of spores of Bacillus species. J. Bacteriol. 192: 3608-3619 (2010)

Zhang P, Thomas SW, Li Y, Setlow P. Effects of cortex peptidoglycan structure and cortex hydrolysis on the kinetics of $\mathrm{Ca}^{2+}$. dipicolinic acid release during Bacillus subtilis spore germination. J. Bacteriol. 194: 646-652 (2012)

Publisher's Note Springer Nature remains neutral with regard to jurisdictional claims in published maps and institutional affiliations. 